\title{
High and Persistent Excretion of Hepatitis A Virus in Immunocompetent Patients
}

\author{
Grace M.S. Tjon, ${ }^{1}$ Roel A. Coutinho, ${ }^{2,3}$ Anneke van den Hoek, ${ }^{1}$ Sylvia Esman, ${ }^{1}$ \\ Clementine J. Wijkmans, ${ }^{4}$ Christian J.P.A. Hoebe, ${ }^{5}$ Bert Wolters, ${ }^{6}$ Corien Swaan, ${ }^{7}$ \\ Ronald B. Geskus, ${ }^{1,8}$ Nicole Dukers, ${ }^{1,2}$ and Sylvia M. Bruisten ${ }^{1,2} *$ \\ ${ }^{1}$ Department of Infectious Diseases, Public Health Service of Amsterdam, 1000 CE, Amsterdam, The Netherlands \\ ${ }^{2}$ Department of Human Retrovirology, Academic Medical Center, University of Amsterdam, \\ Meibergdreef 15, Amsterdam, The Netherlands \\ ${ }^{3}$ Center for Infectious Diseases Control, National Institute of Public Health and the Environment, \\ A. van Leeuwenhoeklaan 9, Bilthoven, The Netherlands \\ ${ }^{4}$ Municipal Health Service "Hart voor Brabant", Den Bosch, The Netherlands \\ ${ }^{5}$ Department of Infectious Diseases, Municipal Health Service of South Limburg, Heerlen, The Netherlands \\ ${ }^{6}$ Municipal Health Service of Groningen, Groningen, The Netherlands \\ ${ }^{7}$ Municipal Health Service of Zuid-Holland Noord, Leiden, The Netherlands \\ ${ }^{8}$ Department of Clinical Epidemiology \& Biostatistics, Academic Medical Center, University of Amsterdam, \\ Meibergdreef 15, Amsterdam, The Netherlands
}

The duration and level of virus excretion in blood and faeces of patients with hepatitis A virus (HAV) infection were studied in relation to levels of alanine aminotransferase (ALT), disease severity and HAV genotype. Clinical data, blood and faeces were collected from 27 patients with acute hepatitis $A$ (median age: 33 years) for a maximum of 26 weeks. Single blood donations from 55 other patients with acute HAV (median age: 32 years) were also used. Virus loads were quantified by competitive nested RT-PCR. HAV was excreted in faeces for a median period of 81 days after disease onset, with $50 \%$ of patients still excreting high levels at Day $36\left(2 \times 10^{6}-2 \times 10^{8}\right.$ copies $/ \mathrm{ml}$ faeces suspension). Viraemia was detected, but not quantifiable, for a median period of 42 days. In the first 10 days of illness, higher ALT levels were correlated with higher viraemia levels. Comparison of patients infected with genotype $1 \mathrm{a}$ with those infected with type $1 \mathrm{~b}$ did not differ significantly in terms of the duration of HAV excretion or jaundice. In conclusion, faecal excretion of HAV is at a high titre in the first month, perhaps making patients infectious for a longer period than assumed currently. Blood banks should be aware that viraemia may be present for more than 1 month, and genotype did not affect the duration of virus excretion or jaundice. J. Med. Virol. 78:1398-1405, 2006. ๑ 2006 Wiley-Liss, Inc.

KEY WORDS: HAV excretion; HAV viraemia; HAV levels

\section{INTRODUCTION}

Hepatitis A virus (HAV) belongs to the Picornaviridae family and is classified in its own genus, Hepatovirus. Infection takes place mainly via the faecal-oral route through person-to-person contact. In the late incubation period and at onset of illness very large numbers of HAV particles are excreted in faeces until alanine aminotransferase (ALT) reaches peak elevation [Ciocca, 2000]. Therefore, patients with HAV are considered contagious from 1-2 weeks before onset of symptoms until 12 weeks afterward [Koff, 1998; Center for Disease Control and Prevention, 2004]. However, faecal excretion can last up to 3 months and longer [Yotsuyanagi, 1996; Costa-Mattioli et al., 2002a], indicating that patients may be contagious for a longer period than assumed previously.

In addition to faecal excretion, the virus is also present in blood [Center for Disease Control and Prevention, 2004]. HAV viraemia can exceed 3 months in immunocompetent patients [Bower et al., 2000;

Reporting and interviewing of hepatitis A cases were done at the Dutch Public Health Services of Amsterdam, Brabant, South Limburg, Groningen, South-Holland South and South-Holland North. HAV RNA isolation, detection, quantification and sequencing were performed at the Public Health Service of Amsterdam, The Netherlands.

*Correspondence to: Sylvia M. Bruisten, Public Health Service of Amsterdam (Streeklaboratorium voor de Volksgezondheid), Nieuwe Achtergracht 100, 1018 WT Amsterdam, The Netherlands. E-mail: sbruisten@ggd.amsterdam.nl

Accepted 11 July 2006

DOI 10.1002/jmv.20711

Published online in Wiley InterScience

(www.interscience.wiley.com) 
Costa-Mattioli et al., 2002b; Sagnelli et al., 2003; Normann et al., 2004] and in one HIV-infected patient, it was detected for 256 days [Costa-Mattioli et al., 2002a]. Parenteral transmission has been reported by blood transfusion and blood products [Mannucci et al., 1994; Soucie et al., 1998] underlining the importance of detection of HAV viraemia. However, data on the duration of HAV excretion remain limited.

Because acute HAV infection is self-limiting, longitudinal studies in which clinical data are collected along with samples are uncommon. For a follow-up study, blood and faecal samples were collected from 27 patients with acute hepatitis A infection for a maximum period of 26 weeks. Our aim was to determine the median duration of HAV excretion in faeces and blood and thus the period of possible infectiousness. Additionally, in 55 other patients whose HAV had been typed [van Steenbergen et al., 2004], it was investigated whether the degree of liver damage affected duration and level of HAV excretion in faeces and viraemia level, and whether HAV genotype affected the duration of HAV excretion and jaundice.

\section{MATERIALS AND METHODS}

\section{Participants}

For the follow-up study, all patients who were positive for anti-HAV immunoglobulin M (anti-HAV $\operatorname{IgM}(+)$ ) and reported between August 2003 and August 2004 to the Public Health Services in Amsterdam, Brabant, South Limburg, Groningen, South-Holland South and South-Holland North were approached.

Participants were asked to sign an informed consent form and to donate a maximum of nine faecal samples and three blood samples over 26 weeks. To prevent distress in children younger than 12 years, they were not required to donate multiple blood samples, but only the one sample used for detecting anti-HAV IgM. The participants were divided at random into groups $A$ and $B$ to donate on different schedules (Table I) to obtain a maximum number of time points after infection. In weeks 1-4 after start of symptoms, participants donated three faecal samples; in weeks 5-26 they donated one faecal sample every 4 weeks. If three consecutive faecal samples were negative in the HAV PCR before the end of the 26-week period, follow-up for that patient was stopped. Adults were asked to donate three blood samples in the first 4 weeks of illness, but a few samples were received after more than 4 weeks. Participants were asked to complete a structured questionnaire each time they sent in a faecal sample. It asked about the presence and duration of symptoms such as jaundice, vomiting, nausea, fatigue, medications and co-infections. The blood samples were used to determine levels of ALT to quantify liver damage. Patients with ALT levels above normal, that is, $>45 \mathrm{IU} / \mathrm{L}$ blood $\left(37^{\circ} \mathrm{C}\right)$, were considered to have abnormal liver function.

Additionally, blood samples were used representing 55 sporadic HAV cases who participated previously in an HAV typing study [Bruisten et al., 2001; van

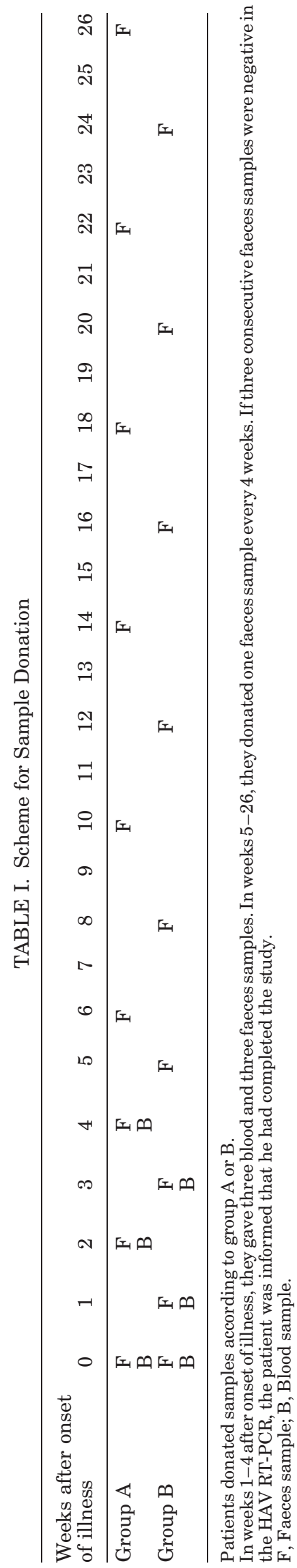

J. Med. Virol. DOI 10.1002/jmv 
Steenbergen et al., 2004], to study the relation between the degree of liver damage and the virus load. Patients were reported from December 2000 to February 2004 to the Amsterdam health service (HS).

\section{Time Definition}

Because the production date of the faecal samples was often unknown, the date on which it was received was used. The sampling time was calculated as the days between the first day of symptoms (jaundice) and the date the sample was received. Sampling time in blood was the number of days between the first day of symptoms and the donation date.

Blood and faecal samples from individual follow-up participants were considered to be measured in the same period (i.e. one measurement), if faeces were provided within 5 days after giving a blood sample.

\section{RNA Isolation, Detection, Sequencing and Phylogenetic Analysis}

RNA extraction, nested RT-PCR, sequencing and phylogenetic analysis were carried out as described previously [Bruisten et al., 2001; van Steenbergen et al., 2004; Tjon et al., 2005]. The detection RT-PCR was carried out in an end volume of $25 \mu \mathrm{l}$ with an input of $5 \mu \mathrm{l}$ RNA from patient material.

Random hexamer primers were used for reverse transcription. PCR primers for nested amplification of the VP3-VP1 region and the VP1-P2a region of the HAV genome were used as described previously [Bruisten et al., 2001; van Steenbergen et al., 2004; Tjon et al., 2005]. All primers were synthesised by Isogen Life Science (Maarssen, The Netherlands).

\section{Construction of Competitor RNA}

The competitor was created from RNA isolated from virus culture $\mathrm{HAV}_{\text {cyt/HB1.1 }}$ [Brack et al., 1998] with Tripure isolation reagent (Roche, Almere, The Netherlands). Full-length HAV RNA was resuspended in $50 \mu \mathrm{l}$ Tris- $\mathrm{HCl}(10 \mathrm{mM}, \mathrm{pH} 8.0)$ and stored at $-80^{\circ} \mathrm{C}$ until use.

The method was adapted from Diviacco et al. [1992]. Two RT-PCRs were performed with the Access RT-PCR kit (Promega, Leiden, The Netherlands). The sequences of the primers used in the RT-PCR reactions are shown in Table II. The $25 \mu \mathrm{l}$ RT-PCR mixtures contained $0.5 \mu \mathrm{l}$ $\mathrm{HAV}_{\text {cyt/HB1.1 }} \mathrm{RNA}, 1 \times \mathrm{AMV} / \mathrm{Tfl}$ reaction buffer, $200 \mu \mathrm{M}$ dNTP, $1.5 \mathrm{mM} \mathrm{MgSO}$, $10 \mathrm{ng}$ of the sense and the anti-sense primer, 0.1 U AMV reverse transcriptase and $0.1 \mathrm{U}$ Tfl DNA polymerase. The RT step was carried out at $48^{\circ} \mathrm{C}$ for $45 \mathrm{~min}$ and $94^{\circ} \mathrm{C}$ for $2 \mathrm{~min}$. Subsequently, 35 amplification cycles were carried out at $94^{\circ} \mathrm{C}$ for $30 \mathrm{sec}, 55^{\circ} \mathrm{C}$ for $30 \mathrm{sec}, 68^{\circ} \mathrm{C}$ for $90 \mathrm{sec}$, and terminated with $68^{\circ} \mathrm{C}$ for $7 \mathrm{~min}$. The amplification products of RT-PCR1 (175 bp) and RT-PCR2 (222 bp) contain an overlapping region of $20 \mathrm{bp}$ with restriction sites EcoRI and HindIII (Table II). This region was used for 1:1 hybridisation of PCR1 and PCR2 amplimers. Subsequently, $0.2 \mu \mathrm{l}$ of the mixture and primers VP1-4-senseNcoI and VP1-6-SalI (Table II) were added in a $25 \mu \mathrm{lPCR}$ mix and amplification was carried out [Bruisten et al., 2001]. The resulting $397 \mathrm{bp}$ amplimer was verified on a $1 \%$ agarose gel, isolated with the Qiagen gel extraction kit (Qiagen Benelux B.V., Venlo, The Netherlands) and dissolved in $50 \mu \mathrm{l}$ Tris-HCl (10 mM, pH 8.0). The fragment was cloned into a $\operatorname{pGEM} 5 \mathrm{Zf}(+)$ vector and grown in JM109 bacteria (Promega Benelux B.V., Leiden, The Netherlands). Plasmid DNA was isolated from a recombinant clone and linearised by incubation at $95^{\circ} \mathrm{C}$ for $2 \mathrm{~min}$ and placement on ice for $5 \mathrm{~min}$. Competitor RNA was made using T7 polymerase (Promega Benelux B.V.) and contaminating DNA was removed with RQ1 Dnase (Promega Benelux B.V.) according to the manufacturers' protocols.

\section{Quantitative RT-PCR}

Serial dilutions of competitor RNA were amplified by nested PCR with and without an RT step according to Bruisten et al. [2001] to determine the presence of contaminating DNA. Dilution samples that were negative in the PCR reactions without the RT step were used for quantitative RT-PCR with patient material. Two methods were used for calculating the concentration of the competitor RNA. The first method was based on the OD260 value measured by spectrophotometer of the competitor RNA, which was 0.024 , and the Avogadro formula. The total length of the competitor RNA is 443 nucleotides, resulting in a concentration of the competitor RNA starting solution of $4 \times 10^{11}$ copies/ $\mu$ l. The second method was based on the fact that RNA detection by RT-PCR is possible from 10 to 20 copies per reaction, assuming a $10 \%$ efficiency of the cDNA step and the potency to detect 1-2 copies of target cDNA. Using this method we calculated that the concentration of the competitor RNA starting solution was about $4 \times 10^{12}$ copies/ $/$ l. The average of these numbers was calculated

TABLE II. Primer Sequences Used in the Two RT-PCRs to Construct the Competitor

\begin{tabular}{llll}
\hline & Primer & \multicolumn{1}{c}{ Sequence 5'-3' $^{\prime}$} & Nucl nr ${ }^{\mathrm{a}}$ \\
\hline RT-PCR1 & VP1-4s NcoI & TAC/CATGGcgttgcttcccatgtcaga & $2131-2149$ \\
& VP-mut-as EcoRI/HindIII & ccGAATT/CcgcgAAGC/Ttgcaacattctgttctgtagaaa & $2259-2278$ \\
RT-PCR2 & VP1-6 SalI & GCG/TCGACcatatgatctgatgtatgt & $2455-2473$ \\
& VP-s-mut EcoRI/HindIII & gcA/AGCTTcgcgG/AATTCggccagatccccagttgtat & $2279-2298$ \\
\hline
\end{tabular}

aNucleotide numbering is according to strain $\mathrm{HAV}_{\text {cyt HB1.1 }}$ [Brack et al., 1998]. The underlined part of the primer sequences written in capital letters indicates restriction sites. The EcoRI/HindIII sites are in a 20 bp region, which is present in the competitor sequence but not in wild-type HAV. 
and the competitor concentration was set at $2 \times 10^{12}$ copies/ $\mu$ l.

Serial tenfold dilutions of the competitor RNA were divided into aliquots with Tris- $\mathrm{HCl}(10 \mathrm{mM}, \mathrm{pH} 8.0)$ containing $0.5 \mathrm{U} / \mu \mathrm{l}$ Rnasin. The quantitative RT-PCR was performed according to the HAV RT-PCR protocols described previously [van Steenbergen et al., 2004; Tjon et al., 2005] in an end volume of $25 \mu \mathrm{l}$ with an input of $2 \mu \mathrm{l}$ competitor RNA and $2 \mu \mathrm{l}$ RNA from patient material. Amplification of the competitor resulted in an amplicon of $267 \mathrm{bp}$, while the amplicon size of patient-derived HAV cDNA was $247 \mathrm{bp}$. The qualitative RT-PCR had a higher sensitivity than the quantitative RT-PCR concerning detection of patient-derived HAV RNA because no competitor RNA was added. Hence, HAV RNA detected with the qualitative RT-PCR was not always quantifiable. The number of HAV copies in a stool sample were calculated per millilitre of a 10\%-20\% suspension of fresh stool in phosphate buffered saline; hereafter referred to as "faeces suspension". Quantitation was possible from virus load levels of $2 \times 10^{3}$ copies/ $\mathrm{ml}$ faecal suspension and from $1 \times 10^{3}$ copies $/ \mathrm{ml}$ blood.

\section{Statistical Analysis}

Statistical analyses were performed with SAS [SAS statistical package, 2005b], R [R statistical package, 2005a] and SPSS 12.0 [SPSS 12.0, 2005c] software for Windows. The distribution of the time until virus loads in faeces and blood were below a certain level was estimated, for example undetectable by RT-PCR, using the nonparametric maximum likelihood estimator for interval censored data [Groeneboom, 1996].

Relations between the three markers (ALT and virus levels in blood and in faeces) were analysed in a linear regression model after transformation to the log-scale. For each marker combination, two models were fitted; each marker was used as dependent variable to predict the other.

The Mann-Whitney test was used to determine if HAV genotype influenced duration of HAV excretion in faeces and/or jaundice. The test was also used to determine if liver damage influenced the duration of HAV excretion, comparing patients with ALT levels above and below the median of $1,000 \mathrm{IU} / \mathrm{ml}$ blood.

\section{RESULTS}

\section{General Characteristics of Participants}

Follow-up study. Of the anti-HAV IgM positive cases reported from August 2003 to 2004 at the participating health services, 27 people participated in the follow-up study. As shown in Table III, these included 18 men and 9 women (median age 33 years; interquartile range (IQR) 23-42 years), of whom 17 persons were infected with subtype 1a strains (63\%), 7 with subtype $1 \mathrm{~b}$ strains (26\%) and 3 with subtype $3 \mathrm{a}$ strains (11\%).

All but two participants reported jaundice. Of these, $84 \%(21 / 25)$ also reported the duration of jaundice,
TABLE III. Characteristics of the Participants in the Follow-Up and the HAV Typing Study

\begin{tabular}{lcc}
\hline & Follow-up study & HAV typing study \\
\hline $\begin{array}{l}\text { No. of patients } \\
\text { Median age (years) }\end{array}$ & $27(\mathrm{IQR} 23-42)$ & 55 \\
$\begin{array}{l}\text { Gender } \\
\text { Male }\end{array}$ & $18(67 \%)$ & $43(78 \%)$ \\
Female & $9(33 \%)$ & $12(22 \%)$ \\
Genotype & $17(63 \%)$ & $39(71 \%)$ \\
1a & $7(26 \%)$ & $14(25.5 \%)$ \\
1b & $3(11 \%)$ & $2(3.6 \%)$ \\
3a & $25 / 27(93 \%)$ & $49 / 55(89 \%)$ \\
Jaundice & $\mathrm{NA}$ \\
Median duration of & 17 & $\mathrm{NA}$ \\
$\quad$ jaundice (days) & & \\
Median duration of & 81 & \\
$\quad$ HAV excretion & & \\
$\quad$ days) & & \\
\hline
\end{tabular}

NA, not applicable.

which lasted for a median period of 17 days (IQR: 574 days). Comparing patients infected with genotype 1a versus genotype $1 b$, we found no significant difference in duration of jaundice (Mann-Whitney test: $P=0.89$ ) or duration of HAV excretion in faeces $(P=0.13)$.

\section{HAV-Typing Study Participants}

These 55 patients consisted of 43 men and 12 women (median age: 32 years; IQR 12-38 years) (Table III). There were 39 persons infected with subtype 1a strains (71\%), 14 with subtype $1 \mathrm{~b}(25.5 \%)$ and 2 with subtype $3 \mathrm{a}$ (3.6\%). Of the total, 49 persons (89\%) reported jaundice.

\section{Time Course of Virus Load Levels and ALT Among Patients}

In concordance with the comparisons mentioned above, there were no observable differences per genotype concerning the course of HAV excretion. In The Netherlands, there are two main risk groups among whom different HAV genotypes circulate: homosexual men are infected with genotype 1a strains, while travelers to HAV endemic countries are infected mainly with either genotype $1 \mathrm{~b}$ strains (Morocco, Turkey, etc.) or genotype 3a strains (Pakistan, India) [van Steenbergen et al., 2004]. The patterns of patients infected with genotype $1 \mathrm{a}, 1 \mathrm{~b}$ or $3 \mathrm{a}$ are shown in Figure 1a-c.

Figure 1a represents a 26 -year-old homosexual man infected with a genotype 1a strain. He reported anonymous sex in saunas as a risk factor. He was jaundiced for 16 days and a HAV faecal excretion was detected up to 98 days after disease onset.

Figure 1b depicts a 31-year-old patient who was infected in Morocco with a genotype 1b strain. He was jaundiced for 21 days, and virus excretion was detected until 70 days after onset of illness.

Figure 1c represents an 11-year-old patient who became infected in Pakistan with a genotype 3a strain. The patient was jaundiced for 18 days and HAV excretion was detected for 76 days. 

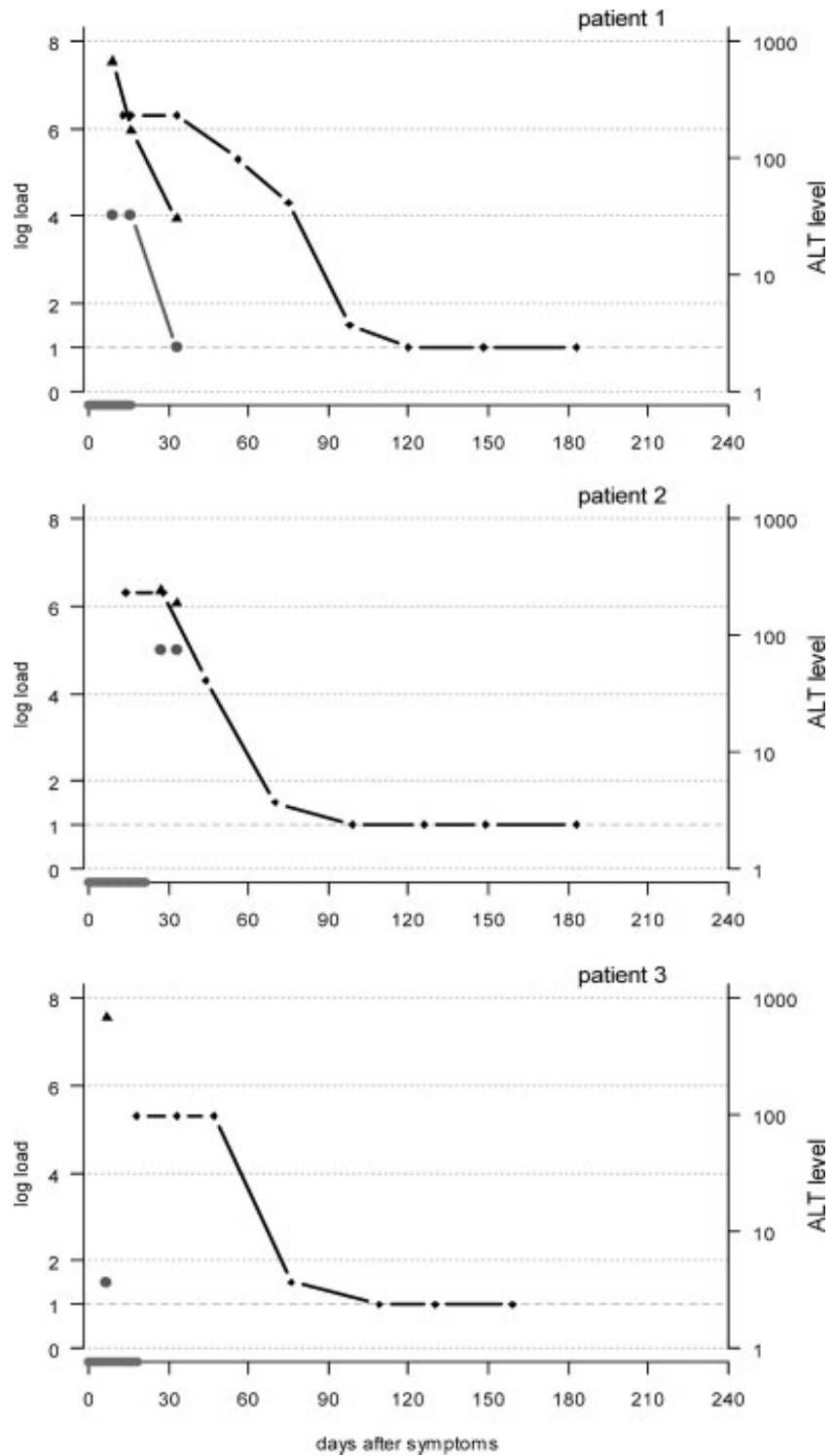

Fig. 1. a-c: Time course of virus load and ALT level in three patients. The left Y-axis shows the logarithm of virus load in linear scale per $\mathrm{ml}$ faeces suspension or per $\mathrm{ml}$ blood. Logload $=1$ : detection limit qualitative RT-PCR. Logload=1.5: detection limit quantitative RT-PCR. Logload =2: Quantification limit. The right Y-axis shows the ALT levels in log scale in IU/ml blood. The X-axis shows the number of days after onset of symptoms. Duration of jaundice is depicted by the grey bar on the X-axis. a: Patient 1 is a 26 -year-old homosexual man who got infected with a type 1a virus by anonymous sex in public venues. He was jaundiced for 16 days. b: Patient 2 is a 31 -year-old man who got infected with a genotype $1 \mathrm{~b}$ strain in Morocco. He was jaundiced for 21 days. c: Patient 3 is an 11-year-old boy who got infected with a genotype $3 a$ strain in Pakistan. He was jaundiced for 18 days.

\section{HAV Detection and Quantitation in Faeces}

Hepatitis A virus (HAV) faecal excretion was detected for an estimated median period of 81 days after onset of symptoms in samples of the 27 follow-up study participants (Fig. 2). Faecal excretion was never shorter than 57 days, with a maximum of 127 days. Fifty percent of the participants still excreted at least $2 \times 10^{6}-2 \times 10^{8}$ copies $/ \mathrm{ml}$ faeces suspension at 36 days after onset of

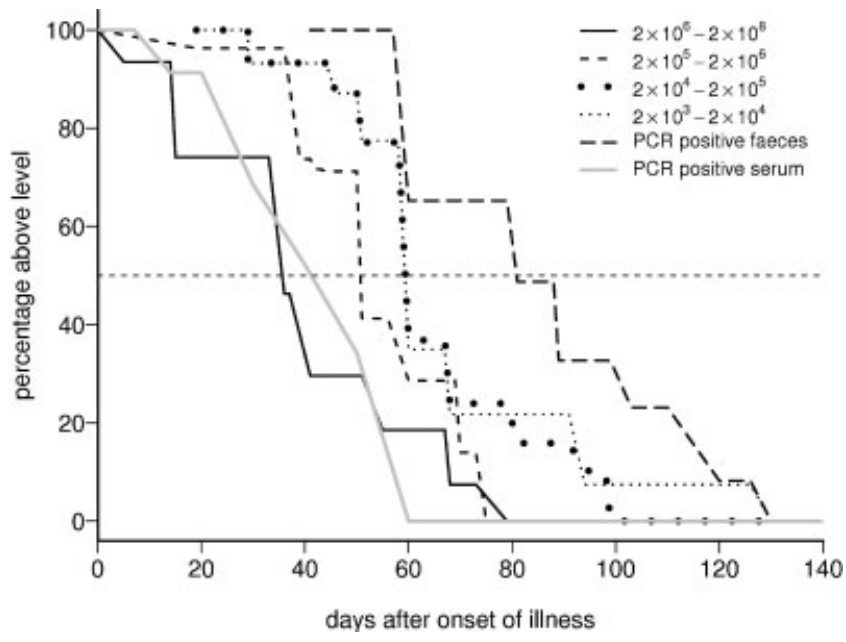

Fig. 2. Curves for virus excretion levels at different time points. The black curves show the estimated percentage of patients over time that have a virus load in faeces above a certain limit. The grey curve shows the last time points at which sera were HAV-positive in the qualitative RT-PCR. The horizontal line is the median value.

symptoms. After 65 days this had declined to $10 \%$ of patients. The lowest quantifiable level, $2 \times 10^{3}$ copies $/ \mathrm{ml}$ faeces suspension, was detected for a median period of 60 days.

\section{HAV Detection and Quantitation in Blood}

In the follow-up study $(n=27)$, serum samples were provided from 1 day before onset of illness to 74 days after the onset of symptoms. The estimated median period in which HAV was detected in blood was 42 days after disease onset (Fig. 2). At 60 days after the onset, all blood samples were estimated to be HAV-negative.

The PCR results of the sera provided by participants of both the follow-up and HAV typing study are shown in Figure 3. In total, 119 samples taken from 82 participants were tested, since 22 follow-up patients donated more than one blood sample. Again, we found that the proportion of PCR-positive sera declined over time. It

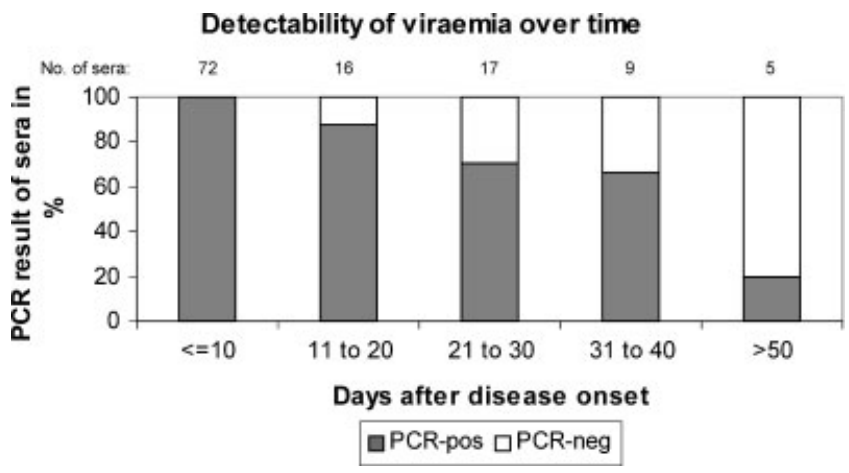

Fig. 3. Detectability of HAV viraemia according to days after onset of illness. The Y-axis shows the percentage of PCR-positive (grey) blood samples donated by participants of the follow-up and the HAV-typing study. All 72 sera (100\%) donated within the first 10 days of illness were PCR-positive, whereas $80 \%$ of the sera donated more than 40 days after onset were PCR-negative. 
was $100 \%$ in the period up to 10 days after onset of illness and declined to $20 \%$ after 40 days (Fig. 3 ).

Taking into account one serum sample per patient obtained at different time points after the onset of disease, it was found that the median virus load levels varied at different time points. In the first 10 days of illness, the median virus load level was $1 \times 10^{6} \mathrm{copies} / \mathrm{ml}$ blood (95\% confidence interval (CI): $5.2 \times 10^{5}-1.9 \times 10^{6}$ copies $/ \mathrm{ml}$ blood; $\mathrm{n}=69$ ). After 10 days, the median virus load of the donated sera was below quantitation level $\left(<10^{3}\right.$ copies $\left./ \mathrm{ml}\right)$.

\section{Relation Between ALT Levels and Virus Levels in Blood and in Faeces}

ALT levels and virus load in blood. To determine if the degree of liver damage influenced virus levels in blood in the first 10 days of illness and vice versa, data were analysed from follow-up and HAV typing-study participants $(n=64)$. Spearman analysis revealed a significant association between liver damage and the HAV level in serum $(\rho=0.354 ; P=0.004)$. This was corroborated by the results from linear regression analysis, which showed that if ALT levels decreased with $1 \log _{10} \mathrm{IU} / \mathrm{L}$ blood, viraemia levels decreased with $0.81 \log _{10}$ copies $/ \mathrm{ml}$ blood $(P=0.017)$, and vice versa, if viraemia levels decreased with $1 \log _{10}$ copies $/ \mathrm{ml}$ blood, ALT levels decreased with $0.11 \log _{10}$ IU/L blood $(P=0.017)$. To minimize the confounding effect of time, these analyses were repeated with data of the first 5 days of illness, which yielded similar results.

ALT levels and virus load in faeces. Nine participants provided blood and faeces in the same period (5 days) within the first 10 days of illness. Using Spearman analysis, a strong positive correlation was found between the virus level in blood and in faeces $(\rho=0.942 ; P<0.01)$. No significant correlation was found between ALT levels and virus load in faeces during this period $(\rho=0.248 ; P=0.520$ ).

ALT levels and duration of HAV excretion in faeces. The possible relation between liver damage and the duration of HAV excretion in faeces was of interest. Upon analysis, no difference was found in duration of HAV excretion between persons with ALT levels above the median (1,000 IU/ml blood) versus ALT levels below the median in the first 10 days of illness (Mann-Whitney test: $P=0.5 ; \mathrm{n}=16$ ).

\section{DISCUSSION}

Due to the acute and self-limiting nature of HAV infection, sequential collection of samples combined with clinical data from patients is uncommon. Information on the duration and level of HAV excretion in blood and in faeces is therefore limited despite its importance for disease control.

To elucidate these matters, clinical data and serial blood and faeces samples were collected from 27 acute hepatitis A patients for half a year. The biochemical and clinical data were combined with quantitative RT-PCR results to study possible relations between symptomatic disease and the duration and level of HAV excretion.

In other studies, the real-time PCR method was used to quantify HAV loads in sera. These real-time PCRs target the $5^{\prime}$ noncoding region and virus loads were quantified with an external standard [Costa-Mattioli et al., 2002b; Rezende et al., 2003; Normann et al., 2004].

At the onset of this study, a real-time PCR was compared with a competitive nested RT-PCR, targeting the VP3-VP1 region (data not shown). An internal standard was used for both virus quantitation, and as an inhibition control for PCR of faeces-derived RNA samples. Tests using the real-time PCR showed a significant increase in the fluorescent signal representing amplification of the internal standard, whereas almost no increase in fluorescent signal was detected for amplification of the wild-type HAV cDNA. Nevertheless, both the internal standard and the wild-type HAV cDNA were amplified during the reaction, since amplicons of the expected sizes were visible on acryl-amide gels. Unfortunately, we were not able to solve this problem and therefore chose to use the competitive nested RTPCR that is described in the present study, as this yielded more reproducible and robust results.

The results show that HAV is detectable in faeces for a median period of 81 days after onset of symptoms, with a maximum of 127 days. Although the literature on this subject is sparse, studies with fewer patients describe similar findings of HAV excretion periods in faeces from 52 days post-onset up to 89 days in healthy individuals [Yotsuyanagi, 1996; Polish et al., 1999; Flehmig et al., 2000; Chitambar et al., 2001; Costa-Mattioli et al., 2002a]. HIV-positive persons may excrete the virus for even longer periods, since one study found that an HIV-1 infected person still excreted $5 \times 10^{6}$ copies/g faeces 106 days after the onset of illness [Costa-Mattioli et al., 2002a].

Of our patients, $50 \%$ were still shedding HAV in faeces at 36 days, at the same high levels as at disease onset (Fig. 2). One study reported successful infection of two tamarins by inoculation with a suspension of faeces donated 27 days after the ALT peak of the human patient [Polish et al., 1999]. The animals seroconverted and excreted HAV in blood and in faeces after 15 and 21 days, respectively. Thus, patients still excreting high levels of HAV in faeces after 1 month may still be infectious.

Sera collected during the present study were HAV RNA-positive for a median period of 42 days after illness. Other studies report viraemic periods varying from 22 up to 490 days [Bower et al., 2000; Kwon et al., 2000; Ida et al., 2002; Costa-Mattioli et al., 2002b; Sagnelli et al., 2003; Normann et al., 2004].

Although HAV transmission by blood products is rare, there have been several reports on HAV outbreaks due to contaminated blood products [Mannucci et al., 1994; Robertson et al., 1998; Soucie et al., 1998; Chudy et al., 1999; Gowland et al., 2004; Heitmann et al., 2005]. To prevent contamination of blood products in The Netherlands, HAV patients are excluded from donating 
blood for 4 weeks after clinical symptoms are resolved, or 6 weeks in the case of contact with a HAV patient. Since the patients had jaundice for a median period of 17 days, and elevated ALT levels for a median period of 16 days, the present study suggests that most HAV patients are probably HAV RNA-negative by the end of the 46 weeks of exclusion. However, blood donors without any HAV symptoms and those with prolonged viraemia must also be taken into account, especially since donated blood is not tested for the presence of HAV in The Netherlands. An even greater risk to blood supplies is present during the period before HAV antibodies, increased liver enzyme levels and HAV symptoms are detected [Gowland et al., 2004; Heitmann et al., 2005]. Weimer et al. [2002] reported a window period of 2 weeks in which HAV-infected patients had high HAV levels in blood with normal ALT levels before onset of illness. PCR techniques can reduce this window period and increase the safety of blood products, especially since HAV is 10,000 times more infectious by the intravenous route than orally, and contaminated blood products can increase morbidity and mortality in already ill patients treated with these products [Purcell et al., 2002].

It was found that in the first 10 days after onset of illness, ALT levels were correlated positively with viraemic levels in blood. However, no indications were found that the degree of liver damage during this period influenced duration of HAV excretion in faeces. Other studies have found that ALT and HAV levels in blood are correlated positively [Fujiwara et al., 1997; Normann et al., 2004; Sainokami et al., 2005]. The results of the present study support the findings of Bower et al. [2000] who detected HAV levels of $10^{4}-10^{5}$ plaque forming units (pfu)/ml up to 20 days prior to the ALT peak. These levels declined to $1-10 \mathrm{pfu} / \mathrm{ml} 30$ days after the ALT peak.

The factors that cause liver damage during HAV infection are still poorly understood. One hypothesis is that hepatic disease is caused by the patient's immune system as it attempts to clear the virus [Vallbracht et al., 1986; Brack et al., 2002; Rezende et al., 2003]. Age and underlying disease, as well as medication, can influence disease outcome. Rezende et al. [2003] reported that patients with HAV-related fulminant hepatitis had low HAV levels in blood in spite of hepatocyte necrosis. This finding is in agreement with Sainokami et al. [2005] who found that ALT levels and virus load were significantly correlated in patients with mild HAV-related symptoms, but not in those with severe symptoms. In contrast to the position in vivo, wild-type HAV can persistently infect human cell lines without causing observable cytopathogenicity [Vallbracht et al., 1984]. Cytotoxic peripheral blood lymphocytes taken from HAV patients have been shown to induce cytolysis in HAV-infected cell cultures, whereas lymphocytes from noninfected persons did not have this effect [Vallbracht et al., 1986; Maier et al., 1988]. Accordingly, one would expect immunocompromised persons to have persistent HAV infection. Reportedly, immunocompromised HIVinfected persons are HAV-viraemic for a longer period than expected [Ida et al., 2002; Costa-Mattioli et al., 2002a] and one study found that they show less elevated ALT levels and are longer viraemic than HIV-negative patients [Ida et al., 2002]. Another study found that neonates still excreted HAV 4-5 months after infection [Rosenblum et al., 1991]. Hence, our finding that the virus load in blood is associated positively with liver damage supports the notion that HAV clearance in hepatocytes is immunomodulated.

On the other hand, increased disease severity may be associated with viral factors, such as genotype and nucleotide changes in, for example the $5^{\prime}$-nontranslated-region of the virus [Fujiwara et al., 2002]. No indication was found in this study that genotype influenced duration of jaundice or HAV excretion, nor did other studies looking for an association between HAV genotype and disease severity [Fujiwara et al., 2003; Rezende et al., 2003; Normann et al., 2004]. The findings show that HAV faecal excretion is high in the first month of illness, suggesting that patients may be infectious for a longer period than currently assumed. Furthermore, HAV patients can be viraemic for up to 2 months, which has to be taken into account by blood banks. Finally, a positive association was found between ALT and viraemia levels during the first 10 days of illness.

\section{ACKNOWLEDGMENTS}

The authors thank the patients who participated in this study for their adherence to the requested procedures in collecting clinical data and samples; the nurses of the participating Public Health Services for approaching eligible study participants and collecting the data and samples, with special thanks to Gabriella Morroy, MD, Jolanda Koel-van Driel, Kirsten Vrijman, Hans Frantzen, Karin Oudshoorn, Lenneke Ruhaak, B.J. den Hoedt. We also thank Alex Koek for laboratory assistance, Colette Smit M.Sc. for statistical and epidemiological support, Lucy Phillips for editing the manuscript and the anonymous reviewers for their comments.

\section{REFERENCES}

Bower WA, Nainan OV, Han X, Margolis HS. 2000. Duration of viremia in hepatitis A virus infection. J Infect Dis 182:12-17.

Brack K, Frings W, Dotzauer A, Vallbracht A. 1998. A cytopathogenic, apoptosis-inducing variant of hepatitis A virus. J Virol JID 0113724 72:3370-3376.

Brack K, Berk I, Magulski T, Lederer J, Dotzauer A, Vallbracht A. 2002. Hepatitis A virus inhibits cellular antiviral defense mechanisms induced by double-stranded RNA. J Virol 76:11920-11930.

Bruisten SM, Steenbergen van JE, Pijl AS, Niesters HGM, Doornum van GJJ, Coutinho RA. 2001. Molecular epidemiology of hepatitis A virus in Amsterdam. J Med Virol 63:88-95.

Center for Disease Control and Prevention. 2004. Diagnosis and Management of Foodborne Illnesses. www.cdc.gov/mmwr/preview/ mmwrhtml/rr5304a1.htm. 16-4-2004.

Chitambar SD, Joshi MS, Sreenivasan MA, Arankalle VA. 2001. Fecal shedding of hepatitis A virus in Indian patients with hepatitis A and in experimentally infected Rhesus monkey. Hepatol Res 19:237246.

Chudy M, Budek I, Keller-Stanislawski B, McCaustland KA, Neidhold S, Robertson BH, Nubling CM, Seitz R, Lower J. 1999. A new cluster 
of hepatitis A infection in hemophiliacs traced to a contaminated plasma pool. J Med Virol 57:91-99.

Ciocca M. 2000. Clinical course and consequences of hepatitis A infection. Vaccine 18:S71-S74.

Costa-Mattioli M, Allavena C, Poirier AS, Billaudel S, Raffi F, Ferre V. 2002a. Prolonged hepatitis A infection in an HIV-1 seropositive patient. J Med Virol 68:7-11.

Costa-Mattioli M, Monpoeho S, Nicand E, Aleman MH, Billaudel S, Ferre V. 2002b. Quantification and duration of viraemia during hepatitis A infection as determined by real-time RT-PCR. J Viral Hepat JID - 9435672 9:101-106.

Diviacco S, Norio P, Zentilin L, Menzo S, Clementi M, Biamonti G, Riva S, Falaschi A, Giacca M. 1992. A novel procedure for quantitative polymerase chain reaction by coamplification of competitive templates. Gene 122:313-320.

Flehmig B, Normann A, Bohnen D. 2000. Transmission of hepatitis A virus infection despite vaccination. N Engl J Med 343:301-302.

Fujiwara K, Yokosuka O, Ehata T, Imazeki F, Saisho H, Miki M, Omata M. 1997. Frequent detection of hepatitis A viral RNA in serum during the early convalescent phase of acute hepatitis A. Hepatology 26:1634-1639.

Fujiwara K, Yokosuka O, Ehata T, Saisho H, Saotome N, Suzuki K, Okita K, Kiyosawa K, Omata M. 2002. Association between severity of type A hepatitis and nucleotide variations in the $5^{\prime}$ nontranslated region of hepatitis A virus RNA: Strains from fulminant hepatitis have fewer nucleotide substitutions. Gut 51:82-88.

Fujiwara K, Yokosuka O, Imazeki F, Saisho H, Saotome N, Suzuki K, Okita K, Tanaka E, Omata M. 2003. Analysis of the genotypedetermining region of hepatitis A viral RNA in relation to disease severities. Hepatol Res 25:124-134.

Gowland P, Fontana S, Niederhauser C, Taleghani BM. 2004. Molecular and serologic tracing of a transfusion-transmitted hepatitis A virus. Transfusion 44:1555-1561.

Groeneboom P. 1996. Inverse problems in statistics. Proceedings of the St. Flour Summer School in Probability, 1994. Lecture Notes in Math.1648, 67 - 164. 1648, Berlin, Germany: Springer Verlag. 67164

Heitmann A, Laue T, Schottstedt V, Dotzauer A, Pichl L. 2005. Occurrence of hepatitis A virus genotype III in Germany requires the adaptation of commercially available diagnostic test systems. Transfusion 45:1097-1105.

Ida S, Tachikawa N, Nakajima A, Daikoku M, Yano M, Kikuchi Y, Yasuoka A, Kimura S, Oka S. 2002. Influence of human immunodeficiency virus type 1 infection on acute hepatitis A virus infection. Clin Infect Dis 34:379-385.

Koff RS. 1998. Hepatitis A. Lancet 351:1643-1649.

Kwon OS, Byun KS, Yeon JE, Park SH, Kim JS, Kim JH, Bak YT, Kim JH, Lee CH. 2000. Detection of hepatitis A viral RNA in sera of patients with acute hepatitis A. J Gastroenterol Hepatol 15:10431047

Maier K, Gabriel P, Koscielniak E, Stierhof YD, Wiedmann KH, Flehmig B, Vallbracht A. 1988. Human gamma interferon production by cytotoxic $\mathrm{T}$ lymphocytes sensitized during hepatitis A virus infection. J Virol 62:3756-3763.

Mannucci PM, Gdovin S, Gringeri A, Colombo M, Mele A, Schinaia N, Ciavarella N, Emerson SU, Purcell RH. 1994. Transmission of hepatitis A to patients with hemophilia by factor VIII concentrates treated with organic solvent and detergent to inactivate viruses. The Italian Collaborative Group. Ann Intern Med 120:1-7.
Normann A, Jung C, Vallbracht A, Flehmig B. 2004. Time course of hepatitis A viremia and viral load in the blood of human hepatitis A patients. J Med Virol 72:10-16.

Polish LB, Robertson BH, Khanna B, Krawczynski K, Spelbring J, Olson F, Shapiro CN. 1999. Excretion of hepatitis A virus (HAV) in adults: Comparison of immunologic and molecular detection methods and relationship between HAV positivity and infectivity in tamarins. J Clin Microbiol JID - 7505564 37:36153617.

Purcell RH, Wong DC, Shapiro M. 2002. Relative infectivity of hepatitis A virus by the oral and intravenous routes in 2 species of nonhuman primates. J Infect Dis 185:1668-1671.

$\mathrm{R}$ statistical package. 2005a. http://www.r-project.org.

Rezende G, Roque-Afonso AM, Samuel D, Gigou M, Nicand E, Ferre V, Dussaix E, Bismuth H, Feray C. 2003. Viral and clinical factors associated with the fulminant course of hepatitis A infection. Hepatology 38:613-618.

Robertson BH, Alter MJ, Bell BP, Evatt B, McCaustland KA, Shapiro CN, Sinha SD, Souci JM. 1998. Hepatitis A virus sequence detected in clotting factor concentrates associated with disease transmission. Biologicals 26:95-99.

Rosenblum LS, Villarino ME, Nainan OV, Melish ME, Hadler SC, Pinsky PP, Jarvis WR, Ott CE, Margolis HS. 1991. Hepatitis A outbreak in a neonatal intensive care unit: Risk factors for transmission and evidence of prolonged viral excretion among preterm infants. J Infect Dis JID - 0413675 164:476-482.

Sagnelli E, Coppola N, Marrocco C, Onofrio M, Scarano F, Marotta A, Scolastico C, Catuogno A, Salzillo A, Sagnelli C, Piccinino F Filippini P. 2003. HAV replication in acute hepatitis with typical and atypical clinical course. J Med Virol 71:1-6.

Sainokami S, Abe K, Ishikawa K, Suzuki K. 2005. Influence of load of hepatitis A virus on disease severity and its relationship with clinical manifestations in patients with hepatitis A. J Gastroenterol Hepatol 20:1165-1175.

SAS statistical package. 2005b. www.sas.com

Soucie JM, Robertson BH, Bell BP, McCaustland KA, Evatt BL. 1998. Hepatitis A virus infections associated with clotting factor concentrate in the United States. Transfusion 38:573-579.

SPSS 12.0 for Windows. 2005c. www.spss.com.

Tjon GM, Wijkmans CJ, Coutinho RA, Koek AG, Van den Hoek JA Leenders AC, Schneeberger PM, Bruisten SM. 2005. Molecular epidemiology of hepatitis A in Noord-Brabant, The Netherlands. J Clin Virol 32:128-136.

Vallbracht A, Hofmann L, Wurster KG, Flehmig B. 1984. Persistent infection of human fibroblasts by hepatitis A virus. J Gen Virol 65:609-615.

Vallbracht A, Gabriel P, Maier K, Hartmann F, Steinhardt HJ, Muller C, Wolf A, Manncke KH, Flehmig B. 1986. Cell-mediated cytotoxicity in hepatitis A virus infection. Hepatology 6:1308-1314.

van Steenbergen JE, Tjon G, Van Den Hoek A, Koek A, Coutinho RA Bruisten SM. 2004. Two years' prospective collection of molecular and epidemiological data shows limited spread of hepatitis A virus outside risk groups in Amsterdam, 2000-2002. J Infect Dis JID 0413675 189:471-482

Weimer T, Streichert S, Watson C, Groner A. 2002. Hepatitis A virus prevalence in plasma donations. J Med Virol 67:469-471.

Yotsuyanagi H. 1996. Prolonged fecal excretion of hepatitis A virus in adult patients with hepatitis $\mathrm{A}$ as determined by polymerase chain reaction. Hepatology 24:10-13. 